\section{IJßER}

ISSN: 2149-5939
International Journal of Social Sciences and Education Research

Online, http://dergipark.gov.tr/ijsser

Volume: 3(1), 2017

\title{
Kadare's lexicon opposite the lexicon of the Albanian language
}

\author{
Luljeta Adili-Çeliku ${ }^{1}$
}

\begin{abstract}
Received Date: 03 / 09 / 2016
Accepted Date: 12 / $11 / 2016$

Abstract

It has been some time now that Ismail Kadare's literary and artistic values have been spoken about. Many studies on his works have also taken place. The reason lies beyond his extraordinary and pleasant style as well as his linguistic capabilities that make him so special. He especially excels in the field of the lexicon and vocabulary. He writes in standard Albanian language, meaning that he abides by those spelling and grammatical rules as do the rest of Albanian writers and authors; however, this does not prevent him from expressing his linguistic egoism and peculiarity. This paper is aimed at his language; at his linguistic contributions in the field of word-formation. He creates new words in Albanian in order to clean it from the impact of borrowings and foreign words, and even for stylistic purposes. In this study, we have tried to collect some of Kadare's words in order to illustrate his engagement in this field. His specialty remains in the field of word formation and has to do with the scope he chooses and uses, with the areas where lexical inputs come from and word-formation means. The words have been divided into two groups: in prefixed and suffixed ones. There are also mixed or compound creations. For every new word, the semantic meaning and the word to be replaced have also been given.
\end{abstract}

Keywords: Kadare, input, selection, cleansing, language.

\section{Introduction}

It has been for some time now that our renowned author and writer, Ismail Kadare has been in the focus of domestic and foreign literary critics, including the Albanian Language scholars. This is not the result of some exaggeration of this famous writer who aims at doing with the language what he actually does with his own work: i.e. its creation and recreation. Although the writer's first and last means is the word only, he is not seeking of either modifying or degrading it as such. It is the writer who takes on the responsibility of making his language even better than before. And, this is not an easy task to accomplish. It is neither an easy agreement. It can be achieved through hard work and after a series of exhaustion and meditation as well as convictions that seeking to enrich your language means to interfere with the work of a whole nation and after having accomplished that task, to face the challenges of pertaining to and being consistent with what you have already done.

The Albanian language has a long tradition of enrichment by the authors and writers. If we were to follow the idea that language makes nations, we would not exaggerate to say that language is actually made by poets and writers. We can remember many writers of the antique literature such as Buzuku, Budi, Bogdani, etc. In addition, we can also mention the series of writers of the Renaissance who contributed so much in cultivating the language.

\footnotetext{
${ }^{1}$ Asst. Prof. Dr., South East European University -TETOVO, MACEDONIA 1.adili@ seeu.edu.mk
} 
Adili-Çeliku, L. (2017). Kadare's lexicon opposite the lexicon of the Albanian language. International Journal of Social Sciences and Education Research, 3(1), 9-15.

The writers are the ones who protect and take care of the language. It is a silent and invisible agreement between them and the language itself.

It seems as if the language decides to 'lend' the writer its own words at the beginning of their noble mission only if they promise to take very good care of them and consider them as the most precious and fragile thing in the world.

It is more than weird and amazing to follow Kadare by his initial steps in his mission to enrich the language. The first attempts to introduce the Albanian lexicon can be noticed in his major works such as Dimri i vetmisë së madhe and Koncert në fund të dimrit. They would not have been easy steps for sure. It must have been very difficult and even exhausting, if we were to use Kadare's own words. It is not that the Albanian language could not have expressed purely and precisely the writer's opinions and ideas, the variety of feelings, emotional reactions, spiritual states... all of them were there... the means of expression and spiritual conditions were all there, with centuries in every geographical dimension.

Language, in reality, is alive, and as every other living being, it can be hurt and harmed, and even spoilt. Sometimes the dangers and threats become more aggressive and vivid and perhaps it is easier to defend it at those times. However, they can sometimes be hidden and even very little, though able enough to damage it so much that the process of its recovery could take ages. It has been said so many times so far that it is degradation that Kadare fears the most, to the extent that its recovery would basically be impossible to happen.

\section{Words that are close to entering the Albanian language glossary}

Below we have the words that Kadare has created in order to replace foreign words. All of these words have been collected by his own works. The words are a step towards being inserted in the standard modern Albanian language. The words have been grouped according to their creation, i.e. in prefixed and suffixed words. The possibilities of creating new words or $a l$ banizing foreign words through inflections are limitless. Kadare noticed this early and has used them in the best possible way.

The paper includes the semantic meanings of the words that are meant to be substituted by the writer.

The function of these words is dynamic; the aim of usage of the majority of these words is the full replacement of the respective foreign or borrowed word, whereas a small portion of theirs has merely a stylistic function, without aiming at replacing the respective word, i.e. a possibility of enriching the synonymous vocabulary of the Albanian language.

\subsection{Prefixed words}

shnjohje (anulim; invalidation, annulment);

çujëzuar (i,e) (i/e dehidruar, dehydrated; dried; that has lost its liquidness)

çvendosshëm (i,e) (i çmontueshëm; moveable, mobile)

çmërs (a solid layer remaining on the sides of a boiling dish; Kadare uses this word instead of the foreign word bigorr)

tejndjenjë (intuitë; intuition, created with the aim of cleansing the language) 
Adili-Çeliku, L. (2017). Kadare's lexicon opposite the lexicon of the Albanian language. International Journal of Social Sciences and Education Research, 3(1), 9-15.

mbindezje (ekstazë; ecstasy - a feeling or state of very great happiness)

mbindijesë (intuitë; used to replace the word: intuition - the ability to know something by using your feelings rather than considering the facts).

nënshpjegim (diçiturë; legend - an explanation found at the bottom of a chart; Kadare uses the word to replace the foreign one).

mosdurim (used to replace the word: intolerance - not being willing to accept ideas or ways of behaving that are different from your own).

përndezje - (eksitim; excitement a state deriving from the verb excite, stimulate)

\subsection{Suffixed words}

barnatore (barna (plural of bar (medication)) + suffix 'tore'; pharmacy, chemist's; a commonly used word in Kosovo)

erëmirim ( aromatizim; spraying with attractive odor; the writer used the word instead of perfuming and aromatizing).

gjithësim (gjithësi; Kadare uses the word instead of saying universe)

tërthorizim (announcing something in an indirect way; aluzion; Kadare has replaced this borrowing with a purely Albanian word - allusion).

përndritje (clear light, glow; happiness, joy; Kadare uses this word to replace the word reflex, which is a borrowing).

rrënjësi (autoktoni ; from the word root: being native, autochthonous)

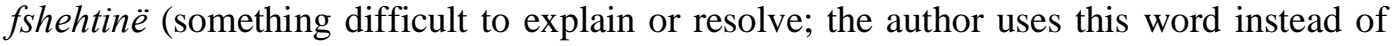
enigmë)

zbrazëtinë (emptiness; an empty space; this word, which could be Kadare's creation as much as a popular one, is used instead of the other word such as boshllëk)

mëparësi (from the adverbial - më parë: being the first, primary, native, original; used instead of autochthonous)

gropacak (whole digger; used with a scornful meaning instead of llagëmxhi)

gjithësor (i gjithësishëm; i përbotshëm; used to replace universal; The novel, as mentioned several times, goes beyond Albania and takes a universal sounding after this new reading )

imtësor (thorough; getting ito details; Kadare prefers this word over the borrowing detailed)

kremtor (referring to celebrations; festive)

krejtësor (entire; overwhelming; general; complete; Kadare uses the word instead of the borrowing total)

truallsor (belonging to the ground, land or territory; that has to do with one's own property. Kadare created this word in order to replace another borrowing territorial)

viganor (related to giants; huge; genius; requiring hard work; Kadare uses this word to replace the borrowing colossal) 
Adili-Çeliku, L. (2017). Kadare's lexicon opposite the lexicon of the Albanian language. International Journal of Social Sciences and Education Research, 3(1), 9-15.

dehshëm (affectionately; used instead of enthusiastically)

vjetran(e) (antique, archaic, old; outdated; used to replace the word archaic)

qiellzanë ( tavan; upper part of something; cover; against the floor; covering a room; ceiling)

fshehtan (hiding something; unclear; enigmatic; used to replace enigmatik-e; ');

gjithkahnajë (world, galaxy, universe )

githnajë (all stellar systems together; galaxy; universe; used to replace the word cosmos)

bujtinar (derives from the word bujtinë + suffix -nar; owner of the inn; the writer replaces other words such as hanxhi, hotelier, hotelxhi with this one)

bujtje (verbal noun from the verb buj / (bujt/ur + je) - stay, accommodate; the action by someone who goes to one's house to stay overnight; the writer uses this word to replace another word like mysafirllëk)

kotherak (from the word kothere + suffix -ak; the one who has been brought up in great poverty; a word from the Tosk dialect which Kadare uses for stylistic and language cleansing purposes)

mbujak(e) (adjective deriving from words such as $m \ddot{e}+u j e \ddot{+}+$ suffix $-a k$; being underwater and absorbing moisture; this Gheg dialect word is used by Kadare along with the word ground replacing the word bashtinë)

pamarrshëm (i,e) (deriving from the adjective pamarre $(i, e)+$ suffix - shëm; having nio feeling of embarrassment; not feeling embarrassed from doing immoral things or saying offensive words; insolent; it is clear that the word marre and the adjective itself come from the Gheg dialect; Kadare brings it as a synonym for i paturp (shameless)

pamashkull (i,e) (from the word mashkull (male) and the prefix pa-; it is said to indicate a person that does not possess masculine features. Kadare uses this to add to the meaning of the borrowed word impotent)

qerthullor(e) (from qerthull+ suffix - or; that has the shape of a circle; that is repeated regularly according to that circle and within a certain time period; circular; round; Kadare uses this word to replace the borrowing cyclic)

dehashpirt (temporary spiritual satisfaction; the writer replaces the word ecstasy with this one)

frymëza (astma; asthma a medical condition of the chest that makes breathing difficult)

arkëmort (arkivol; coffin a box in which a dead body is buried)

ogurzezë (makabë; macabre unpleasant and strange because connected with death and frightening things)

vetasgjësim (autodestruksion; self -destruction do destroy one's self by different means...)

i /e gjithunjshëm (universal; universal done by or involving all the people in the world or in a particular group; true or right at all times and in all places) 
Adili-Çeliku, L. (2017). Kadare's lexicon opposite the lexicon of the Albanian language. International Journal of Social Sciences and Education Research, 3(1), 9-15.

i/e palëndët (abstract; abstract -existing in thought or as an idea but not having physical reality)

rrokarmë (alarm; alarm fear and anxiety that someone feels when something dangerous or unpleasant may happen)

padoras (anonim/e; anonymous not known)

i/e gjithsejtë ( total/e; total general, total, full, complete, dealing with its entirety...)

We will also mention some examples to illustrate the depth and will with which Kadare treats literary-linguistic issues when it comes to foreign suffixes used in Albanian language, such as -llëk and $-x h i$. Here we should note his sharp eye in catching the tiniest and finest details which he later treats in accordance with the rules of the language in which he writes.

çarturi (budallallëk; derived from the adjective $i$ çartur: a state of high motivation and inspiration; delirium, rave, anxiety, nightmare, craziness, etc.)

gomarëri (gomarllëk; fatal mistake; great craziness)

matufëri (matufllëk; being dotard, senile)

\subsection{Words formed using foreign suffixes}

A small number of words created by Kadare appear with foreign suffixes, mainly Turkish, such as -llëk and - hane.

More than disseminating or reemphasizing the expansion of these words in Albanian, the usage of these suffixes in Kadare's works is solely for stylistic purposes. They belong more to the characters that he has created and the time when the plot takes place, rather than to the writer himself.

Even though it may seem insufficient, we have presented only those words that looked familiar to us, without getting into the precise determination of their origin, i.e. some of them may belong to the Turkish language; however, we have decided to place them in the group of new words due to the conviction that these words, even if they did not exist as such, they would have been created by the author, knowing that Kadare has been very skillful in using a series of foreign suffixes.

We are presenting below some of Kadare's words formed by using foreign suffixes. In his works, we can also notice hybrid words, whereupon the word-forming stem can be Albanian whereas the suffix - foreign.

dylberhane (a brothel for male homosexuals)

jetimllëk (the state of being an orphan);

mysafirhane (a special room in the house designed to welcome guests only)

rruspihane (a brothel with women (for men); stylistic usage of the word shtëpi publike)

\section{Conclusion}

At times of turmoil, when the language is 'attacked' by global languages, and when the technical-technological development has reached its summit, Kadare, with his peculiar foresight and his extraordinary sensitivity, aims at digging out from the gold mines of the Albanian 
Adili-Çeliku, L. (2017). Kadare's lexicon opposite the lexicon of the Albanian language. International Journal of Social Sciences and Education Research, 3(1), 9-15.

language some forgotten words, used in remote locations, that have a uniqe beauty and attractiveness, unused or rarely used words, which Kadare revives after they were gone for quite a long time.

This paper contains a bunch of Kadareian words, as mentioned above, which aim at replacing the foreign words and borrowings in Albanian. Words come to us through his works, with the hope that one day they will become part of the standard Albanian language.

This secondary role of his, of a language grandee, this transposition of his from a writer to a linguist, dialectologist and word creator, was foretold by Kadare himself a long time ago, when he was writing the novel "Ura me tre harqe", saying that Gjon Ukcama was alone in seeking to leave traces of written Albanian at times when the Balkans was ruled by the Ottoman Empire.

\section{References}

\section{Scientific literature}

Akademia e Shkencave e Republikës së Shqipërisë, Drejtshkrimi i gjuhës shqipe. Tiranë, 1973

Akademia e Shkencave e Republikës së Shqipërisë, Fjalori drejtshkrimor i gjuhës shqipe. Tiranë, 1976 Akademia e Shkencave e Republikës së Shqipërisë, Fjalori i gjuhës shqipe. Tiranë, 2004 Akademia e Shkencave e Republikës së Shqipërisë, Gramatika e gjuhës shqipe I. Tiranë,1995

Akademia e Shkencave e Republikës së Shqipërisë, Gramatika e gjuhës shqipe II. Tiranë,1995

\section{Ismail Kadare's cited and referred works:}

Kadare, Ismail. Tri këngë zie për Kosovën. Tiranë: Onufri,1998,1999,2003

Kadare, Ismail. Pallati i ëndrrave. Tiranë: Onufri,1999,2003

Kadare, Ismail. Ikja e shtërgut. Tiranë: Onufri, 1999,2003

Kadare, Ismail. Qorrfermani. Tiranë: Onufri,1999

Kadare, Ismail. Vjedhja e gjumit mbretëror. Tiranë: Onufri,1999

Kadare, Ismail. Ra ky mort e u pamë. Tiranë: Onufri, 1999,2000

Kadare, Ismail. Kronikë në gurë. Tiranë: Onufri, 2000

Kadare, Ismail. Bisedë përmes hekurash. Tiranë: Onufri, 2000

Kadare, Ismail. Lulet e ftohta të marsit. Tiranë: Onufri, 2000

Kadare, Ismail. Përballë pasqyrës së një gruaje. Tiranë: Onufri, 2001

Kadare, Ismail. Eskili ky humbës i madh. Tiranë: Onufri, 2001,2003

Kadare, Ismail. Gjenerali i ushtrisë së vdekur. Tiranë: Onufri, 2001

Kadare, Ismail. Jeta, loja dhe vdekja e Lul Mazrekut. Tiranë: Onufri, 2002

Kadare, Ismail. Stinë e mërzitshme në Olimp. Tiranë: Onufri, 2002

Kadare, Ismail. Autobiografia e popullit në vargje. Tiranë: Onufri, 2002

Kadare, Ismail. Pasardhësi. Tiranë: Onufri, 2003

Kadare, Ismail. Hija. Tiranë: Onufri, 2003

Kadare, Ismail. Kështjella. Tiranë: Onufri, 2003

Kadare, Ismail. Vajza e Agamenonit. Tiranë: Onufri, 2003

Kadare, Ismail. Prilli i thyer. Tiranë: Onufri, 2003

Kadare, Ismail. Ura me tri harqe. Tiranë: Onufri, 2004

Kadare, Ismail. Ftesë në studio. Tiranë: Onufri, 2004

Kadare Ismail. Shkaba. Tiranë: Çabej, 2004 
Adili-Çeliku, L. (2017). Kadare's lexicon opposite the lexicon of the Albanian language. International Journal of Social Sciences and Education Research, 3(1), 9-15.

Kadare, Ismail. Poshtërimi ballkanik. Tiranë: Onufri, 2004

Kadare, Ismail. Ditë kafenesh. Tiranë: Onufri, 2005

Kadare, Ismail. Dantja i pashmangshëm. Tiranë: Onufri, 2005

\section{Kadare's volumes by 'Fayard' publishing house}

VEPRA, vëllimi i parë, Paris, 1993

VEPRA, vëllimi i dytë, Paris, 1994

VEPRA, vëllimi i tretë, Paris, 1995

VEPRA, vëllimi i katër, Paris, 1996

VEPRA, vëllimi i pestë, Paris, 1997

VEPRA, vëllimi i gjashtë, Paris, 1998

VEPRA, vëllimi i shtatë, Paris, 1999

VEPRA, vëllimin i tetë, Paris, 2000

VEPRA, vëllimi i nëntë, Paris, 2001 